\title{
Biological activity of wheat germ agglutinin relative to spring wheat plants under the influence of hapten $\mathbf{N}$-acetyl-D-glucosamine
}

\author{
O. V. Kyrychenko \\ Institute of Plant Physiology and Genetics, NAS of Ukraine \\ 31/17, Vasylkivska, Kyiv, Ukraine, 03022 \\ azoleki@ukr.net
}

\begin{abstract}
Aim. To study the biological activity of wheat germ agglutinin (WGA) relative to the spring wheat plants under the influence of N-acetyl-D-glucosamine (hapten of WGA, GlcNAc) at pre-sowing treatment of seeds. Methods. Inhibitory analysis as well as physiological (pot experiments, estimation of the plants growth and development, wheat grain productivity) and biochemical (chlorophyll $a+b$ content) methods. Results. It was shown in the pot experiments that WGA $(100 \mathrm{nM})$ at the pre-sowing of seeds stimulated the growth processes and the plants vegetative mass formation (shoot mass increased from 10 to $24 \%$ in different ontogenesis phases) as well as the chlorophyll $(a+b)$ accumulation in leaves (from 1.2 to 1.4 times), which led to an increased level of realization of wheat grain productivity (the grain number, weight per plant and 1000 grain weight increased by 26,26 and $6 \%$ respectively). Hapten of WGA $\mathrm{N}$-acetyl-D-glucosamine $(100 \mathrm{mM})$ inhibited the positive effects of wheat lectin on the plants: from 5 to $19 \%$ (by the vegetative mass), from 0 to $18 \%$ (by the level of green photosynthetic pigments), from 3 to $13 \%$ (by the grain productivity). The maximum inhibitory effect of hapten was noted in the tillering and boot development phases of wheat ontogenesis. Conclusions. The biological activity of WGA at the pre-sowing treatment of spring wheat seeds was expressed in the intensification of plant growth and development, the active accumulation of chlorophyll in leaves and an increase in the wheat grain productivity. Hapten had a significant reducing effect on the biological activity of wheat lectin resulted in inhibition of positive lectin's effects on physiological and biochemical parameters of the spring wheat plants development. It is one of the arguments in favour of the lectin nature of these effects.
\end{abstract}

Ke y w o r d s: wheat germ agglutinin, hapten, Triticuma estivum L., treatment of seeds, chlorophyll, grain productivity.

2020 O. V. Kyrychenko; Published by the Institute of Molecular Biology and Genetics, NAS of Ukraine on behalf of Biopolymers and Cell. This is an Open Access article distributed under the terms of the Creative Commons Attribution License (http://creativecommons.org/licenses/by/4.0/), which permits unrestricted reuse, distribution, and reproduction in any medium, provided the original work is properly cited 


\section{Introduction}

The use of ecological biotechnology elements (microbial inoculants and biologically active substances of natural origin) in the rural economy in order to increase the crop productivity of culture plants is the urgent issue of sustainable agriculture. Microbial biotechnology and biologically active substances of natural origin (plants and microbial metabolites) are employed in agriculture to fulfill environmental and industrial tasks $[1,2]$. Phytolectins are natural substances, the products of plants metabolism [3, 4]. Lectins are the molecules with a wide range of biological activities [5-9]. They are glycoproteins or oligomeric proteins with one or more sugar-binding sites per subunit. Lectins bind reversibly with specific sugars [10]. Carbohydrate specificity is a fundamental characteristic of the phytohemagglutinin molecules $[10,11]$. Wheat germ agglutinin (WGA) belongs to the group of $\mathrm{N}$-acetyl-Dglucosamine (GlcNAc)-binding plant lectins. WGA has two primary and two secondary independent sugar-binding sites and possesses sugar binding specificity for two types of $\mathrm{N}$-acetylated sugars $-\mathrm{N}$-acetyl-D-glucosamine and $\mathrm{N}$-acetylneuraminic acid [4].

Recently, it has been shown the inducing effects of WGA on the RNA amount, enzyme (peroxydase and catalase) activity of antioxidant system of plant protection, endogenous lectin activity and flavonoids content in wheat leaves and the content of plant hormones (cytokinins and IAA) as well as on the nitrogen fixation activity of rhizospheric microorganisms $[7,12]$.

The aim of the present investigation was to study the biological activity of wheat germ agglutinin (WGA). It was investigated an influence of N-acetyl-D-glucosamine (hapten of WGA, GlcNAc) at the pre-sowing treatment of spring wheat seeds on the wheat plants characteristics: growth parameters, chlorophyll (Chl) $a+b$ content and grain productivity of Triticuma estivum L. in greenhouse conditions.

\section{Material and Methods}

Spring wheat (Triticuma estivum L.) cv Rannya 93 plants [13] were grown on sand soil with components of Pryanishnikov nutrient medium containing $(\mathrm{g} / \mathrm{kg}): 0.12 \mathrm{NH}_{4} \mathrm{NO}_{3}, 0.269 \mathrm{CaSO}_{4}$, $0.172 \mathrm{CaHPO}_{4}, 0.16 \mathrm{KCl}, 0.025 \mathrm{FeCl}_{3} \cdot 6 \mathrm{H}_{2} \mathrm{O}$, $0.123 \mathrm{MgSO}_{4} \cdot 7 \mathrm{H}_{2} \mathrm{O}$ and microelements $0.007\left(\mathrm{NH}_{4}\right)_{2} \mathrm{MoO}_{4}, 0.007 \mathrm{H}_{3} \mathrm{BO}_{3}, 0.0012$ $\mathrm{MnSO}_{4} \cdot 5 \mathrm{H}_{2} \mathrm{O}, 0.0025 \mathrm{CuSO}_{4} \cdot 5 \mathrm{H}_{2} \mathrm{O}$ as a 0.5 mineral nitrogen norm, which was added to the substrate for plant growth. The experiments were performed in Wagner pots ( 7 per variant, 20 seeds per pot) in greenhouse experiments during three years.

Preparations of wheat germ agglutinin $(100 \mathrm{nM})$ and aminosaccharide N-acetyl-Dglucosamine (100 mM) ("Lectinotest", Lviv, Ukraine) were used [14]. The ratio for composition of lectin with hapten was $1: 1$, where lectin was pretreated with hapten for $1 \mathrm{~h}$. Water was used as control, while WGA and WGA+GlcNAc - as experimental variants for pre-sowing treatment of wheat seeds for $1 \mathrm{~h}$.

The shoot weight (fresh weight, FW) and chlorophyll $(\mathrm{Chl} a+b)$ content in wheat leaves were estimated at seedling development (10 day-old plants), tillering (30 day-old plants), boot development (45-50 day-old plants) and head emergence - flowering (55- 
60 day-old plants) of wheat vegetation phase [15]. Chl $(a+b)$ content in wheat flag leaves was determined according to Arnon after extraction of leaves with dimethylsulfoxide[12]. The level of Chl was measured in four replications and expressed in $\mathrm{mg} \mathrm{g}^{-1} \mathrm{FW}$ leaves. The grain productivity (dry weight, DW of plants and grains) of spring wheat was estimated at ripening phase (90-100 day-old plants) of plants vegetation [15]. Yield structure parameters (weight of one spike, grain number and weight per spike, weight of 1000 grains and harvest index) were estimated.

Statistical evaluation of the results was performed according to Statgraphics software statistical package 5.0. All data presented in the paper are Mean \pm standard error of mean (SEM).

\section{Results}

The obtained results demonstrate that presowing treatment of spring wheat seeds with WGA has stimulated the growth processes and formation of plants biomass, Chl $(a+b)$ content in wheat leaves and wheat yield, but GlcNAc has reduced the stimulatory effect of lectin at all developmental phases under greenhouse conditions (Table 1-3). Shoot mass formation
(Table 1) increased by $10-24 \%$, while GlcNAc has inhibited a positive biological effect of WGA at different phases of wheat plants ontogenesis by 5, 19, 12 and $6 \%$. Hapten had a significant reducing effect on the wheat lectin biological activity regarding growth of spring wheat plants in the phases of tillering and boot development. At the same time no difference was observed in the phases of seedling development.

Pre-sowing treatment of spring wheat seeds with WGA has increased $\mathrm{Chl}(\mathrm{a}+\mathrm{b})$ content in the wheat leaves at the phases of seedling development by $21 \%$, of tillering by $38 \%$, of boot development phase by $26 \%$, of head emergence - flowering by $19 \%$ (Table 2 ). Hapten had a significant inhibition effect on wheat lectin at the tillering and boot development phases of wheat plants: caused a reducer in Chl content by 18 and $11 \%$ compared with effect of WGA, however, no difference was observed in the wheat at the seedling development and the head emergence - flowering phases.

The analysis of the yield structure has demonstrated that the grain productivity of spring wheat was enhanced due to an increase in the weight of spikes by $25 \%$, number and weight

Table 1. Effect of N-acetyl-D-glucosamine on biological activity of wheat germ agglutinin: shoot formation of spring wheat plants (average for three years)

\begin{tabular}{l|c|c|c|c}
\hline \multirow{2}{*}{ Treatment of seeds } & \multicolumn{4}{|c}{ Phases of wheat plants ontogenesis } \\
\cline { 2 - 5 } & Seedling development [FW] & Tillering [FW] & Boot development [FW] & Ripening [DW] \\
\cline { 2 - 5 } & \multicolumn{4}{|c}{ Shoot weight per plant [g] } \\
\hline Control & $0.41 \pm 0.02$ & $2.31 \pm 0.12$ & $4.16 \pm 0.22$ & $2.14 \pm 0.11$ \\
\hline WGA & $0.45 \pm 0.01^{\mathrm{a}}$ & $2.87 \pm 0.11^{\mathrm{a}}$ & $4.80 \pm 0.30^{\mathrm{a}}$ & $2.42 \pm 0.13^{\mathrm{a}}$ \\
\hline WGA+GlcNAc & $0.43 \pm 0.0^{\mathrm{a}}$ & $2.33 \pm 0.14^{\mathrm{b}}$ & $4.24 \pm 0.24^{\mathrm{b}}$ & $2.27 \pm 0.10^{\mathrm{b}}$ \\
\hline
\end{tabular}

Table 1-3: a - statistically significant difference $(\mathrm{P} \leq 0.5)$ with the control variant, ${ }^{\mathrm{b}}$ - statistically significant difference $(\mathrm{P} \leq 0.5)$ with the WGA variant, “_“" - values were not detected. 
Biological activity of wheat germ agglutinin relative to spring wheat plants under the influence of hapten N-acetyl-D-glucosamine

Table 2.Effect of N-acetyl-D-glucosamine on biological activity of wheat germ agglutinin: chlorophyll content of spring wheat leaves (average for two years)

\begin{tabular}{l|c|c|c|c}
\hline \multirow{2}{*}{ Treatment of seeds } & \multicolumn{4}{|c}{ Phases of wheat plants ontogenesis } \\
\cline { 2 - 5 } & Seedling development & Tillering & Boot development & Ripening \\
\cline { 2 - 5 } & \multicolumn{4}{|c}{ Chl $(a+b)$ content in leaves $\left[\mathrm{mg} \mathrm{g}^{-1} \mathrm{FW}\right]$} \\
\hline Control & $0.87 \pm 0.02$ & $1.27 \pm 0.03$ & $1.72 \pm 0.03$ & $2.05 \pm 0.01$ \\
\hline WGA & $1.05 \pm 0.02^{\mathrm{a}}$ & $1.75 \pm 0.03^{\mathrm{a}}$ & $2.16 \pm 0.06^{\mathrm{a}}$ & $2.44 \pm 0.05^{\mathrm{a}}$ \\
\hline WGA+GlcNAc & $1.05 \pm 0.04^{\mathrm{a}}$ & $1.44 \pm 0.01^{\mathrm{a}}$ & $1.93 \pm 0.03^{\mathrm{ab}}$ & $2.51 \pm 0.02^{\mathrm{a}}$ \\
\hline
\end{tabular}

Table 3. Changes of biological activity of wheat germ agglutinin under the influence of its hapten $\mathrm{N}$-acetylD-glucosamine: grain productivity of spring wheat (structure of harvest, average for three years)

\begin{tabular}{l|c|c|c|c|c}
\hline Treatment of seeds & $\begin{array}{c}\text { Weight of one spike } \\
\text { [g DW] }\end{array}$ & $\begin{array}{c}\text { Grain number per } \\
\text { spike [number] }\end{array}$ & $\begin{array}{c}\text { Grain weight per } \\
\text { spike [g DW] }\end{array}$ & $\begin{array}{c}\text { Weight of 1000 } \\
\text { grains [g DW] }\end{array}$ & Harvest index [HI] \\
\hline Control & $1.19 \pm 0.04$ & $22.8 \pm 0.09$ & $0.88 \pm 0.02$ & $40.91 \pm 0.51$ & $0.36 \pm 0.01$ \\
\hline WGA & $1.49 \pm 0.06^{\mathrm{a}}$ & $28.7 \pm 1.0^{\mathrm{a}}$ & $1.11 \pm 0.02^{\mathrm{a}}$ & $43.45 \pm 0.64^{\mathrm{a}}$ & $0.41 \pm 0.02^{\mathrm{a}}$ \\
\hline WGA+GlcNAc & $1.31 \pm 0.08^{\mathrm{b}}$ & $26.3 \pm 1.5^{\mathrm{a}}$ & $0.97 \pm 0.07^{\mathrm{b}}$ & $41.87 \pm 0.67^{\mathrm{b}}$ & $0.40 \pm 0.01^{\mathrm{a}}$ \\
\hline
\end{tabular}

of grains per spike by 26 and $26 \%$ respectively (Table 3).

An increase in the DW of 1000 grains was insignificant (by $6 \%$ ). The harvest index increased by $14 \%$. This effect suggests that the potential maximum of wheat plants formed in the presence of WGA was directed rather towards the production of wheat grains but not to the plant vegetative mass. GlcNAc has inhibited the activation of biological effects of WGA regarding to spring wheat productivity by $12 \%$ (weight of one spike), by $8 \%$ and $13 \%$ (number and weight of grains per spike respectively). However, no difference has been shown in the values of 1000 grains and harvest index in its variants (by $4 \%$ and $3 \%$ respectively).

The intensification of plant shoot formation (Table 1) and chlorophyll content in leaves (Table 2) as well as the spring wheat yield at WGA use for pre-sowing treatment of seeds
(Table 3) was shown in greenhouse experiments during three years.

\section{Discussion}

Our recent results provide an evidence of the considerable role of exogenous phytolectins as regulators of plant growth and development and physiological activity of the soil nitrogenfixing microorganisms $[2,7,12]$. The response of spring wheat and soil rhizospheric nitrogenfixing microorganisms to the pre-sowing treatment of seeds by wheat germ agglutinin was expressed in the metabolic changes of plants: an increase in RNA amount and endogenous lectin activity in wheat seedlings and leaves, enzyme activity of antioxidant system of plant protection (peroxydase and catalase), endogenous lectin activity and flavonoids content and the amount of endogenous plant hormones cytokinine and auxine nature in wheat leaves $[7,12]$, enhanced accumulation of plant bio- 
mass (Table 1) and an increase in Chl $(a+b)$ content in the wheat leaves (Table 2) as well as the nitrogen-fixing capacity of the rhizospheric microorganisms $[2,7]$. As a result, the wheat grain productivity increased (Table 3 ). Hapten of WGA, aminosaccharide GlcNAc, binds to the active centers of wheat lectin on the level of molecular interaction [14] and partially decreases the activation effects of WGA on the plants physiological and biochemical parameters. It is one of the arguments in favour of the lectin nature of these effects.

It is know that lectins are the molecules exhibiting a wide range of biological activities regarding micro- (virus, bacterium, fungi) and macroorganisms (insects, plants, animals) [2, $5,7,8,16-19]$. Both endogenous and exogenous lectins have many physiological functions in the plants $[3,4,6-8,16,18]$. Literature data confirms the results of our investigation, which have shown that pretreatment of WGA with GlcNAc has inhibited the positive effect of lectin on the wheat plants. It was shown that haptens of lectins blocked the lectin effects on the metabolism activity, physiological and biochemical parameters (like enzyme activities, membrane potential e. a.) of plants. It was reported that treatment of Nicotiana tabacum pollen grains with lectin concanavalin A (Con A) applied at concentrations of 10$1000 \mu \mathrm{g} \mathrm{ml}^{-1}$ has induced hyper polarization of plasma membrane in the vegetative cells and has enhanced pollen grain germination. Con A at a concentration of $100 \mu \mathrm{g} \mathrm{ml}^{-1}$ increased the intracellular $\mathrm{pH}$ by 0.3 units. These effects of Con A were blocked with saccharide methylmannopyranoside at a concentration of $100 \mathrm{mM}$ [16]. Pretreatment of the bacterial lectins with L-fucose has decreased the effects of lectins
[17]. It was shown that incubation of bacterial lectins isolated from the microsymbiont of wheat plant - soil nitrogen-fixing microorganisms Azospirillum brasilense sp.7 and its mutant defective in lectin activity (A. brasilense sp.7.2.3) with the exocomponent, membrane and apoplast fractions of wheat root increased the enzyme activities of $\alpha$-glucosidase, $\beta$ - glucosidase and $\beta$-galactosidase. Lectins of wildtype and mutant strains had stronger stimulatory effect on the activities of all exocomponent fraction enzymes studied and of the apoplast fraction of $\beta$-glucosidase.

Thus, our data (table 1-3) have demonstrated that pre-treatment of WGA with $\mathrm{N}$-acetyl-D-glucosamine changes the biological activity of protein at the pre-sowing treatment of wheat seeds in relation to the spring wheat plants. It is in agreement with previously demonstrated literature data on the inhibitory effect of haptens on the biological activity of lectins. Our research completes and provides the additional evidences for the lectin nature of stimulation effect of the molecules as the biologically active ones on the growth, development and grain productivity of spring wheat plants.

\section{Conclusions}

The biological activity of WGA at the presowing treatment of spring wheat seeds was expressed in the intensification of plant growth and development, the active accumulation of chlorophyll in leaves and an increase in the wheat grain productivity. N-acetyl-Dglucosamine - hapten of wheat lectin had a significant reducing effect on the wheat lectin biological activity that resulted in inhibition of positive lectin effects on physiological and 
biochemical parameters of the spring wheat plants development. It is one of the arguments in favour of the lectin nature of these effects.

\section{REFERENCES}

1. Isobe K, Ohte N. Ecological perspectives on microbes involved in N-cycling. Microbes Environ. 2014; 29(1):4-16.

2. Kyrychenko $O V$. Market analysis and microbial biopreparations creation for crop production in Ukraine. Biotechnol Acta. 2015; 8(4):40-52.

3. Rudiger H, Gabius H-J. Plant lectins: occurrence, biochemistry, functions and applications. Glycoconjugate J. 2001; 18(8): 589-613.

4. Van Damme EJM, Lannoo N, Peumans WJ. Plant Lectins. Adv Botanical Res. 2008; 48:107-209.

5. Singh K, Kaur M, Rup PJ, Singh J. Exploration for anti-insect properties of lectin from seeds of soybean (Glicine max) using Bactrocera cucurbitae as a model. Phytoparasitica. 2006; 34(5):463-73.

6. Jiang $S, M a Z$, Ramachandran $S$. Evolution ary history and stress regulation of the lectin superfamily in higher plants. BMC Evol Biol. 2010; 10(1):79-103.

7. Kyrychenko $O V$. Phytolectins and diazotrophs are the polyfunctional components of the complex biological compositions. Biotechnol Acta. 2014; 7(1):40-53.

8. Pavlovskaya NE, Gagarina IN. The physiological properties of plant lectins as a prerequisite for their application in biotechnology. Khimiya rastitelnogo syriya. 2017; (1):21-35.

9. Hendrickson $O D$, Zherdev AV. Analytical application of lectins. Crit Rev Anal Chem. 2018; 48(4): 279-92.

10. Sharon N. Lectins: carbohydrate-specific reagents and biological recognition molecules. $J$ Biol Chem. 2007; 282:2753-64.

11. Gabius HJ. The sugar code: why glycans are so important. Bio Systems. 2018; 164:102-11.

12. Kyrychenko $O V$, Volkogon $M V$. Effect of wheat germ agglutinin at the pre-sowing treatment of seeds on the level of cytokinins and auxins in leaves. Reports NAS Ukraine. 2010; (6):144-51.
13. State Register of Plant Varieties Suitable for Dissemination in Ukraine in 2018. Kyiv: Ministry of Agrarian Policy and Food of Ukraine. 2018; 447 p.

14. Kyrychenko $O V$. Change of the wheat lectin activity and degree of its interaction with different components of compositions of lectin nature. Ukr Biokhim Zh. 2006; 78(6):105-12.

15. Kirby EJM, Spink JH, Frost DL, Sylvester-Bradley R, Scott RK, Foulkes MJ, Clare RW, Evans EJ. A study of wheat development in the field: analysis by phases. Eur J Agr. 1999; 11(1):63-82.

16. Timofeeva OA, Nevmerzhitskaia YuYu, Moskovkina $M A$. The activity and composition of wheat cell wall lectins under the action of low temperatures and calcium signaling system inhibitors. Rus J Plant Physiol. 2010; 57(2):209-16.

17. Ambarova NA, Lutsyk SA. Lectins WGA and LASA as selective histochemical markers of rat kidney. AML. 2018; 24(2):39-44.

18. Matveeva ND, Andreyuk DS, Lasareva EA, Ermakov IP. The effect of concanavalin A on membrane potential and intracellular $\mathrm{pH}$ during activation in vitro of tobacco pollen grains. Rus J Plant Physiol. 2004; 51(4):494-9.

19. Alenkina SA, Payusova OA, Nikitina VE. Effect of Azospirillum lectins on the activities of wheat-root hydrolytic enzymes. Plant Soil. 2006; 283(1-2):147-51.

\section{Біологічна активність аглютиніну зародків пшениці щодо рослин пшениці ярої за дії гаптену N-ацетил-D-глюкозаміну}

\section{О. В. Кириченко}

Мета. Дослідження біологічної активності аглютиніну зародків пшениці (АЗП) щодо рослин пшениці ярої за дії гаптену N-ацетил-D-глюкозаміну за передпосівної обробки насіння. Методи. Інгібіторний аналіз, фізіологічні (вегетаційні досліди, оцінка росту й розвитку рослин, зернової продуктивності пшениці) та біохімічні (вміст хлорофілу в листках) методи. Результати. У вегетаційних умовах показано, що АЗП (100 нМ) за передпосівної обробки насіння стимулював ростові процеси й формування вегетативної маси рослин (надземна маса збільшилась від 10 до $24 \%$ у різні фази онтогенезу), а також накопичення хлорофілу у листках рослин (від 1,2 до 1,4 рази), що обумовило підвищений 
рівень реалізації зернової продуктивності пшениці (кількість і маса зерен у колосі та маса 1000 зерен збільшились на 26, 26 і 6 \% відповідно). Гаптен АЗП $\mathrm{N}$-ацетил-D-глюкозамін (100 мМ) пригнічував позитивні ефекти лектину на рослини: від 5 до 19 \% (за вегетативною масою), від 0 до 18 \% (за рівнем зелених фотосинтетичних пігментів), від 3 до 13 \% (за показника мизернової продуктивності рослин). Максимальний інгібуючий ефект гаптену відзначений у фази кущіння та трубкування пшениці. Висновки. Біологічна активність аглютиніну зародків пшениці за передпосівної обробки насіння проявлялася в інтенсифікації росту й розвитку рослин, активному синтезі хлорофілу в листках і підвищенню зернової продуктивності пшениці ярої. Гаптен суттєво зменшував біологічну активність лектину, у результаті чого блокувались позитивні ефекти його дії на рослини, що є одним із доказів їх лектинової природи.

Кл юч о в і сл ов а: аглютинін зародків пшениці, гаптен, Triticum aestivum L., обробка насіння, хлорофіл, зернова продуктивність.

\section{Биологическая активность агглютинина зародышей пшеницы относительно растений яровой пшеницы под влиянием гаптена N-ацетил-D-глюкозамин}

\section{Е. В. Кириченко}

Цель. Изучение биологической активности агглютинина зародышей пшеницы (АЗП) под влиянием гаптена $\mathrm{N}$-ацетил-D-глюкозамина при предпосевной обработке семян относительно растений пшеницы яровой. Методы. Ингибиторный анализ, физиологические (вегетационные эксперименты, оценка роста и разви- тия растений, зерновой продуктивности пшеницы) и биохимические (содержание хлорофилла в листьях) методы. Результаты. В условиях вегетационных опытов показано, что АЗП (100 нМ) при предпосевной обработке семян стимулировал ростовые процессы и формирование вегетативной массы растений (надземная масса увеличилась от 10 до $24 \%$ в разные фазы онтогенеза), а также накопление хлорофилла в листьях растений (от 1,2 до 1,4 раза), что обусловило повышенный уровень реализации зерновой продуктивности пшеницы (количество и масса зерен в колосе, а также масса 1000 зерен увеличились на 26, 26 и $6 \%$ соответственно). Гаптен АЗП $\mathrm{N}$-ацетил-D-глюкозамин (100 мМ) ингибировал положительные эффекты лектина на растения: от 5 до $19 \%$ (по вегетативной массе), от 0 до 18 \% (по уровню зеленых фотосинтетических пигментов), от 3 до 13 \% (по зерновой продуктивности). Максимальный ингибирующий эффект гаптена отмечен в фазы кущения и трубкования пшеницы. Выводы. Биологическая активность АЗП при предпосевной обработке семян яровой пшеницы проявлялась в интенсификации роста и развития растений, активном накоплении хлорофилла в листьях и повышении зерновой продуктивности пшеницы. Гаптен существенно снижал биологическую активность лектина, в результате чего блокировались положительные эффекты его действия на растения, что является одним из доказательств их лектиновой природы.

К л юч е в ы е с л о в а: агглютинин зародышей пшеницы, гаптен, Triticum aestivum L., обработка семян, хлорофилл, зерновая продуктивность.

Received 11.11.2019 